\title{
EXAMINATION OF OXIDATIVE STRESS PARAMETERS IN EXPERIMENTAL MESENTERIC ISCHEMIA MODEL
}

\author{
Oksidatif Stres Parametrelerinin Deneysel Mezenterik İskemi Modelinde Değgerlendirilmesi
}

\section{Özgur TATLI ${ }^{1}$, Yunus KARACA ${ }^{1}$, Ahmet ALVER ${ }^{2}$, Ahmet MENTEŞE ${ }^{2}$, Esin YULUĞ $\breve{3}^{3}$, Mücahit GÜNAYDIN ${ }^{4}$, Aynur ŞAHİN ${ }^{1}$, Umut ERYİĞiT ${ }^{1}$, Samad Shams VAHDADİ $^{5}$, Ali AYGÜN6}

\author{
${ }^{1}$ Karadeniz Technical University, Faculty of Medicine, Department of Emergency Medicine, TRABZON2 \\ ${ }^{2}$ Karadeniz Technical University, Faculty of Medicine, Department of Biochemistry, TRABZON \\ ${ }^{3}$ Karadeniz Technical University, Faculty of Medicine, Department of Histology and Embryology, TRABZON \\ ${ }^{4}$ Giresun University, Training and Research Hospital, Department of Emergency Medicine, GIRESUN \\ ${ }^{5}$ Tabriz University of Medical Science, Emergency Medicine, Center IIRAN \\ ${ }^{6}$ Ordu University, Department of Emergency Medicine, ORDU
}

\begin{abstract}
Objective: In order to determine the diagnostic value of plasma protein carbonyl, total antioxidant status (TAS), total oxidant status (TOS), oxidative stress index (OSI) and malondialdehyde (MDA) in the diagnosis of acute mesenteric ischemia (AMI).

Material and Methods: In this randomized, controlled experimental study, 30 mature female Sprague-Dawley rats were divided into six groups. Groups 1, 3 and 5 were control groups undergoing laparotomy only. Groups 2, 4 and 6 were mesenteric ischemia groups undergoing laparotomy and superior mesenteric artery ligation. Blood and tissue samples were sampled at 30 minutes (groups 1 and 2), 2 hours (groups 3 and 4) and 6 hours (groups 5 and 6) after surgical procedures.

Results: The difference between the ischemia and control groups in terms of histopathological injury at $30 \mathrm{~min}$ was statistically significant $(\mathrm{p}=0.007)$. Histopathological injury increased over time in the ischemia groups. Histopathological injury was significantly greater in the ischemia groups compared to the control groups (at both 2 and 6 hours) $(P=0.002$ and $P=0.006$ ). No statistically significant difference was observed when the control and ischemia groups were assessed in terms of the oxidative stress parameters plasma protein carbonyl, MDA, TAS, TOS or OSI.

Conclusion: On the basis of the results from this experimental mesenteric ischemia model, while histopathological injury levels differed significantly among the groups, plasma protein carbonyl and other markers of oxidative stress such as MDA, TAS, TOS and OSI levels, did not differ statistically significant between the ischemia and control groups.
\end{abstract}

Keywords: Experimental model, mesenteric ischemia, oxidative markers

\section{ÖZ}

Amaç: Akut mezenterik iskemi (AMI) tanısında, protein karbonil, total antioksidan status (TAS), total oksidan status (TOS), oksidatif stres indeks (OSI) ve malondialdehit (MDA) düzeylerini belirlemek.

Gereç ve Yöntemler: $\mathrm{Bu}$ randomize kontrollü deneysel çalışmada 30 erişkin dişi Sprague-Dawley türü rat 6 grupta incelendi. Grup 1, 3 ve 5 yalnızca laparotomi uygulanan kontrol grubuydu. Grup 2, 4 ve 6 ise hem laparotomi yapılan hem de superior mezenter arteri bağlanan gruptu. 30. dakikada (Grup 1 ve 2), 2. saatte (Grup 3 ve 4) ve 6. saatte (Grup 5 ve 6) cerrahi işlemler sonrası ratlardan kan ve doku örnekleri alındı.

Bulgular: İskemi ve kontrol grupları arasında 30. dakikada histopatolojik hasar farkı istatistiksel olarak anlamlıyd $(P=0.007)$. İskemi gruplarında histopatolojik hasarın zamanla arttığı görüldü. İskemi gruplarında kontrol gruplarına göre (Hem 2. saatin sonunda, hemde 6 . saatin sonunda) histopatolojik hasar anlamlı derecede fazlayd $1(P=0.002, P=0.006)$. Kontrol ve iskemi grupları arasındaki ilişki oksidatif stres parametrelerinden plazma protein karbonil, MDA, TAS, TOS ve OSI ile değerlendirildiğinde, istatistiksel olarak anlamlı bir fark görülmedi.

Sonuç: $\mathrm{Bu}$ deneysel mezenter iskemi modelinde elde edilen sonuçlara göre, gruplar arasında histopatolojik hasar fark1 anlamlı olmasına rağmen, plasma protein karbonil ve oksidatif stresin diğer göstergelerinden MDA, TAS, TOS ve OSI seviyelerinin iskemi ve kontrol grupları arasında istatistiksel olarak anlamlı fark oluşturmadığı görüldü.

Anahtar Kelimeler: Deneysel model, mesenterik iskemi, oksidatif markır 


\section{INTRODUCTION}

Acute mesenteric ischemia (AMI) is a rare indication for emergency surgery and remains a highly fatal disease $(70 \%$ mortality rate) despite improvements in diagnostic and therapeutic methods (1). Early diagnosis of AMI is difficult, and plain abdominal X-ray, abdominal ultrasonography and computerized tomography scan results are often normal, especially in the early stages, although these can be used to rule out other diagnoses $(1,2)$. Angiography of the mesenteric arteries is the most reliable diagnostic method in AMI. However, other laboratory methods for early diagnosis of AMI are needed due to the difficult access, high costs and loss of time inherent in this technique (2). Different serum biomarkers may have a role to play in the early diagnosis of AMI, but none is sufficiently accurate and individually reliable (3).

Free radicals and other oxidants are normal products of aerobic metabolism. Free radicals are always present in biological systems. These affect lipids by increasing lipid peroxidation. Peroxidation leads to the formation of toxic metabolites such as malondialdehyde (MDA) (4). Total antioxidant status (TAS) reflects the organism's total antioxidant defense capacity. TAS and plasma total oxidative status (TOS) are potentially useful biochemical parameters for estimating an organism's oxidative status (5). The oxidative stress index (OSI), the ratio of TOS to TAS, is also an indicator of oxidative stress (6). Protein carbonyls are the marker of protein oxidation (7). An increased level of protein carbonyl has been observed in many diseases, such as Alzheimer's, diabetes, inflammatory bowel disease and arthritis (8-12).

This study was intended to investigate plasma protein carbonyl and other oxidative stress parameters such as TAS, TOS and OSI, and tissue and plasma MDA levels in an experimental AMI model.

\section{MATERIALS AND METHODS}

\section{Study Design}

This was an experimental, randomized, controlled and non-blinded animal study. The protocol was approved by the Local Ethics Committee (No. 2013/11).

\section{Selection of subjects and study protocol}

Thirty mature female Sprague-Dawley rats (8 weeks old, weighing $250 \mathrm{~g}$ to $300 \mathrm{~g}$ ) were used for the study. The animals were kept in steel cages until the day of the study at a room temperature of $22{ }^{\circ} \mathrm{C}$ and were maintained on a 12:12-h light-dark illumination cycle with access to food and water ad libitum. These rats were only used in this experiment. For the last 12 hours before the experiment, they were given only water.

Following a 12-hour fasting period, intramuscular ketamine $(50 \mathrm{mg} / \mathrm{kg})$ and xylazine $(5 \mathrm{mg} / \mathrm{kg})$ were administered for general anesthesia. All rats were cannulated with a 24-gauge venous cannula from the left femoral vein and infused with saline at 4 $\mathrm{mL} / \mathrm{kg}$ /hour. Respiratory rate, oxygen saturation and body temperatures were constantly monitored. The abdominal sites of all subjects in all groups were shaved and cleaned using $10 \%$ povidone iodine. Laparotomy was performed through a midline incision. The superior mesenteric artery was ligated, and aorta bifurcation was performed with a bulldog clamp. Thereafter, the abdominal wall and the peritoneum were sutured using $2 / 0$ silk.

Rats in Group 1 underwent laparotomy only, and blood and tissue samples were collected after $30 \mathrm{~min}$. Rats in Group 2 underwent laparotomy, and the superior mesenteric artery was also ligated. Blood and tissue samples were collected after $30 \mathrm{~min}$. Rats in Group 3 underwent laparotomy only, and blood and tissue samples were collected after 2 hours. Rats in Group 4 underwent laparotomy, and the superior mesenteric artery was also ligated. Blood and tissue samples were collected after 2 hours. In Group 5, rats underwent 
laparotomy only, and blood and tissue samples were collected after 6 hours. In Group 6, rats underwent laparotomy and the superior mesenteric artery was also ligated. Blood sample and tissue samples were collected after 6 hours.

Blood samples were collected by the intracardiac route. All rats were sacrificed under euthanasia. Next, 5-10 $\mathrm{cm}$ distal ileum specimens were placed in $10 \%$ formaldehyde solution after washing with normal saline solution for histopathological examination. Tissue specimens were stained with hematoxylin-eosin (H\&E), embedded in paraffin blocks and examined under light and electronic microscopy.

Blood samples were placed into citrated tubes. These were centrifuged for $10 \mathrm{~min}$ at $3000 \mathrm{rpm}$ and then left for $30 \mathrm{~min}$ for coagulation. The specimens were stored at $80^{\circ} \mathrm{C}$. At the end of the data collection process, all specimens were studied concurrently by a biochemist blinded to the study data and groups. Plasma protein carbonyl, total antioxidant status (TAS), total oxidative status (TOS) and malondialdehyde (MDA) levels were measured, and oxidative stress index (OSI) levels were calculated as the ratio of TOS to TAS.

\section{Laboratory analysis}

\section{Protein Carbonyl Measurement}

Protein Carbonyl (PrC) level in the serum specimens was determined using a colorimetric assay kit in line with the manufacturer's recommendations (Cayman Chemical Company Cat. No. 10005020, Lot No. 0463100). The absorbance of specimens was measured at a light wave of $370 \mathrm{~nm}$ on a VERSA microplate reader (designed by Molecular Devices in California, USA). The results were expressed as $\mathrm{nmol} / \mathrm{mL}$.

\section{Malondialdehyde measurement}

MDA levels were measured using the thiobarbituric acid reactive substance (TBARS) method (14).

Total antioxidant status, total oxidative status and oxidative stress index measurement
Total antioxidant status, total oxidative status and oxidative stress index were measured and calculated using the method developed by Erel (15).

\section{Histopathological Analysis}

At the end of the study, ileum tissues were removed from rats from each group. The tissues were kept in $10 \%$ formaldehyde for 48 hours, dehydrated by passing through graded alcohol series and clarified in xylene. Sections with a thickness of $4 \mu \mathrm{m}$ were taken from paraffin blocks using a fully automated microtome (Leica RM 2255, Tokyo, Japan). Acceptable sections were stained with $\mathrm{H} \& \mathrm{E}$. Histological evaluation of the preparations was performed under light microscopy by an experienced histologist blinded to the study groups. All preparations were assessed for general morphology under light microscopy (Olympus BX 51; Olympus Optical Co., Ltd., Tokyo, Japan). Five different areas of xanthoma preparation in each group were scored semi-quantitatively between 0 and 3 (score 0 : none; 1 : mild; 2: moderate and 3: severe) in terms of inflammatory cell infiltration, hemorrhage, villus association, and villous apical facial epithelium degeneration. These damages were summed, and total damage scores were calculated as in our previous study (16).

\section{Statistical analysis}

Statistical analysis was performed on SPSS 23.0 (IBM, SPSS, Armonk, NY, USA) statistical software. Comparisons of biochemical parameters and histopathological damage scores at the same time intervals between the control and mesenteric ischemia groups were performed using the Mann-Whitney U test. Time-dependent changes in parameters were investigated using Kruskal-Wallis variance analysis with Bonferroni correction. Spearman's correlation analysis was used to assess the relationship between biochemical parameters and histopathological scores. Statistical significance was assumed at a level of $P<0.05$. 


\section{RESULTS}

Chronological changes in biochemical parameters and histopathological damage scores among the groups are shown in Table 1. Light microscopic evaluation of the ileum tissues from the groups revealed normal morphological ileum villus and mucosa structures in Group 1 (Figure 1A). In Group 2, conjunctiva, degeneration in the epithelium, infiltration and inflammatory cell infiltration in the lamina propria were observed (Figure 1B). In Group 3, occasional degeneration was observed in epithelial cells (Figure 1C). In Group 4, extensive degeneration and loss of epithelial cells were observed. Extensive hemorrhage and moderate inflammatory cell infiltration were observed in the lamina propria (Figure 1D). In Group 5 , villus association was significant. Inflammatory cell infiltration was observed in the lamina propria (Figure 1E). In Group 6, significant villus damage and loss were determined. Epithelial loss in the mucosa, hemorrhage and inflammatory cell infiltration were observed in the severe stage (Figure 1F).
Our results showed a statistically significant difference in histopathological damage at $30 \mathrm{~min}$ between the rats undergoing mesenteric ischemia and those undergoing laparotomy only ( $\mathrm{p}=0.007$, groups 1 and 2 ). The degree of injury increased over time in both the control and ischemia groups. Significantly greater injury occurred at 2 and 6 hours in the groups with induced mesenteric ischemia compared to the control group $(\mathrm{p}=0.002$, groups 3 and 4, p=0.006, groups 5 and 6) (Figure 1). However, no difference was determined at any time in any of the biochemical parameters evaluated between the mesenteric ischemia and control groups ( $p>0.05$ ). Correlation results between the biochemical parameters evaluated and total histopathological injury scores are shown in Table 2. On the basis of these results, there was no correlation between any of the biochemical parameters assessed and histopathological damage deriving from mesenteric ischemia.

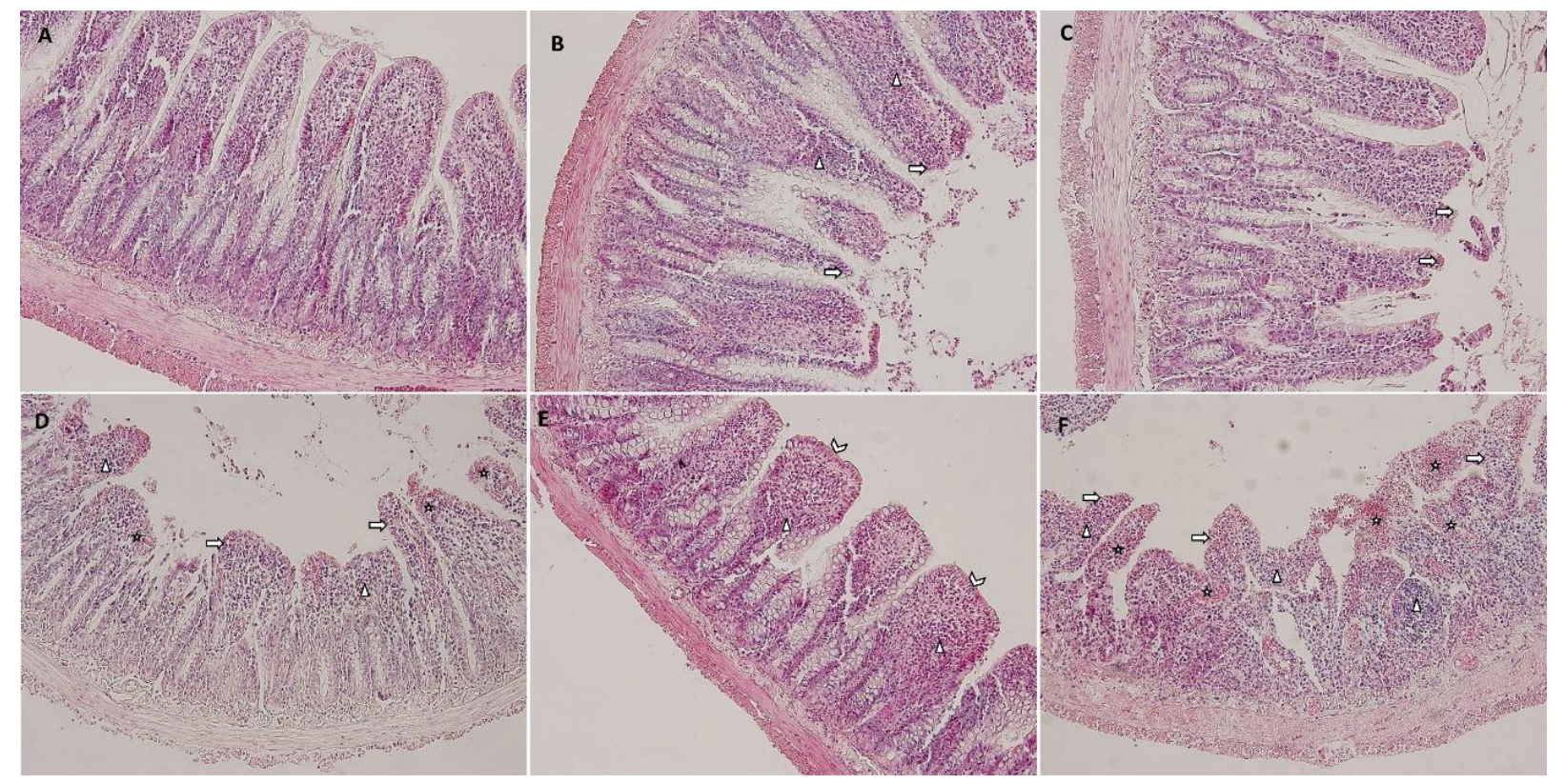

Figure 1: Photomicrographs of the ileum in the different groups (H \& E X 200). (A: Group 1, B: Group 2, C: Group 3, D: Group 4, E: Group 5, F: Group 6) showing loss in the epithelial cells (arrow), inflammatory cell infiltration (arrowhead), hemorrhage (star), and villus association (angular doublet). 
Table 1: Time-dependent changes in protein carbonyl and serum and tissue MDA, TAS, TOS and OSI levels

\begin{tabular}{|c|c|c|c|c|c|c|}
\hline \multirow[b]{3}{*}{ Parameters } & \multicolumn{6}{|c|}{ Times and Groups } \\
\hline & \multicolumn{2}{|c|}{$30 \mathrm{~min}$} & \multicolumn{2}{|c|}{2 hours } & \multicolumn{2}{|c|}{6 hours } \\
\hline & Group I & Group II & Group III & Group IV & Group V & Group VI \\
\hline Protein carbonyl (nmol/ml) & 15.5 & 20.0 & 18.9 & 15.0 & 11.1 & 10.0 \\
\hline Median (25-75\%) & $(7.8-16.0)$ & $(11.7-25.1)$ & $(17.2-19.6)$ & $(12.9-23.5)$ & $(9.4-14.0)$ & $(4.8-18.2)$ \\
\hline Serum MDA(nmol/mL) & 0.640 & 0.420 & 0.440 & 0.370 & 0.390 & 0.490 \\
\hline Median $(25-75 \%)$ & $(0.290-0.800)$ & $(0.365-0.680)$ & $(0.330-0.480)$ & $(0.280-0.520)$ & $(0.355-0.620)$ & $(0.260-0.670)$ \\
\hline Tissue MDA (nmol/g) & 84.0 & 191.0 & 307.0 & 175.0 & 139.0 & 163.0 \\
\hline Median $(25-75 \%)$ & $(58.0-163.5)$ & $(159.5-292.5)$ & $(161.0-345.0)$ & $(107.5-196.0)$ & $(65.5-208.5)$ & $(90.0-208.0)$ \\
\hline TAS (mmol Trolox equivalent/L) & 1.42 & 0.65 & 1.65 & 1.13 & 2.28 & 1.47 \\
\hline Median $(25-75 \%)$ & $(0.47-1.93)$ & $(0.40-1.28)$ & $0.99-2.11$ & $0.55-1.91$ & $1.17-2.38$ & $0.61-2.53$ \\
\hline TOS ( $\mu$ mol H2O2 equivalent/L) & 29.8 & 10.8 & 8.6 & 7.1 & 19.4 & 22.0 \\
\hline Median $(25-75 \%)$ & $(16.1-34.5)$ & $(8.95-26.5)$ & $(4.85-13.1)$ & $(5.85-10.7)$ & $(12.2-30.3)$ & $(15.6-35.2)$ \\
\hline OSI (H2O2/Trolox) & 2.38 & 1.50 & 0.62 & 0.73 & 1.05 & 1.50 \\
\hline Median $(25-75 \%)$ & $(1.22-6.35)$ & $(1.08-6.45)$ & $(0.29-1.58)$ & $(0.48-1.95)$ & $(0.71-1.57)$ & $(0.89-7.96)$ \\
\hline Total Histological Damage Score & 1.0 & 5.0 & 3.0 & 6.0 & 7.0 & 12.0 \\
\hline Median $(25-75 \%)$ & $(1.0-1.5)^{\mathbf{a , d}, \mathbf{e}}$ & $(4.0-6.0)^{\mathrm{a}, \mathrm{g}}$ & $(2.0-4.0)^{\mathbf{b , d ,}, \mathbf{f}}$ & $(4.5-8.0)^{\mathbf{b , h}}$ & $(7.0-7.5)^{\mathbf{c}, \mathbf{e , f}}$ & $(10.5-12.0)^{\mathbf{c}, \mathbf{g , h}}$ \\
\hline \multicolumn{7}{|c|}{$\begin{array}{l}\text { Values were reported as median }(25-75 \%) \text {. } \\
\text { There is no statistically significant difference between groups in terms of protein carbonyl, serum MDA, tissue MDA, TAS, TOS and OSI. } \\
\text { For total histological damage score } \mathrm{a}, \mathrm{p}=0.007 \text { (Group1\&2); } \mathrm{b}, \mathrm{p}=0.02 \text { (Group3\&4); }, \mathrm{p}=0.006 \text { (Group5\&6); } \mathrm{d}, \mathrm{p}=0.012(\mathrm{Group} 1 \& 3) ; \mathrm{e}, \mathrm{p}=0.005(\mathrm{Group} 1 \& 5) ; \mathrm{f} \text {, } \\
\mathrm{p}=0.007 \text { (Group3\&5); } \mathrm{p}=0.008 \text { (Group2\&6); } \mathrm{h}, \mathrm{p}=0.008 \text { (Group4\&6) } \\
\text { (According to the Mann-Whitney U test and Kruskal-Wallis analysis of variance with Bonferroni correction) } \\
\text { MDA, Malondialdehyde; TAS, total antioxidant status; TOS, total oxidant status; OSI, oxidative stress index }\end{array}$} \\
\hline
\end{tabular}


Table 2: Spearman's correlation analysis of histopathological scores and biochemical parameters

\begin{tabular}{|c|c|c|c|c|c|c|c|c|c|c|}
\hline & \multicolumn{2}{|c|}{ PrC } & \multicolumn{2}{|c|}{ Serum MDA } & \multicolumn{2}{|c|}{ Tissue MDA } & \multicolumn{2}{|c|}{ TAS } & \multicolumn{2}{|c|}{ Total histopathological damage score } \\
\hline & $\mathrm{r}$ & $\mathrm{p}$ & $\mathrm{r}$ & $\mathrm{p}$ & $\mathrm{r}$ & $\mathrm{p}$ & $\mathrm{r}$ & $\mathrm{P}$ & $\mathrm{r}$ & $\mathrm{p}$ \\
\hline PrC & & & & & & & & & -0.22 & 0.24 \\
\hline Serum MDA & -0.98 & 0.61 & & & & & & & -0.05 & 0.78 \\
\hline Tissue MDA & 0.31 & 0.09 & 0.05 & 0.81 & & & & & -0.05 & 0.79 \\
\hline TAS & -0.03 & 0.84 & -0.18 & 0.34 & 0.17 & 0.37 & & & 0.12 & 0.52 \\
\hline TOS & -0.25 & 0.17 & 0.21 & 0.24 & -0.18 & 0.33 & 0.11 & 0.58 & 0.13 & 0.17 \\
\hline OSI & -0.21 & 0.28 & 0.22 & 0.22 & -025 & 0.17 & -0.68 & $<0.0001^{*}$ & -0.006 & 0.97 \\
\hline
\end{tabular}

PrC, Protein carbonyl; MDA, Malondialdehyde; TAS, total antioxidant status; TOS, total oxidant status; OSI, oxidative stress index.

*There is a negative strong correlation between OSI and TAS. There is no correlation between any of the biochemical parameters and histopathological damage score. 


\section{DISCUSSION}

AMI must be diagnosed immediately due to its high mortality rates. The most important step in the management of this potentially fatal condition is diagnosis. Insignificant and non-specific clinical findings generally make the diagnosis difficult (17). Systemic inflammatory response syndrome and septic complications are usually responsible for the high mortality rate in AMI (18). Various biochemical parameters have been investigated for diagnosis of AMI (19). In the light of these studies, this study was planned in order to determine the usefulness of plasma protein carbonyl and other oxidative stress markers in the diagnosis of AMI.

Oxidative injury occurs in a biological system if the body's oxidative burden exceeds its antioxidant capacity. Protein and DNA oxidation, lipid peroxidation, and up-regulation of pro-inflammatory cytokines are the main mechanisms involved in oxidative injury (20). The presence of the oxidative stress reaction is an important sign of aggression toward homeostasis and organic systems (21). Plasma Total antioxidant status (TAS), total oxidative status (TOS) and oxidative stress index (OSI), reflect the oxidative balance in the organism and are useful tools for estimating the body's oxidative status (6). Malondialdehyde (MDA) is an end product of lipid peroxidation and a useful marker for determining oxidative injury. Previous studies in the literature have evaluated these biochemical parameters in AMI $(22,23)$.

In an experimental ischemia reperfusion study involving rats, Terzi A et al. observed that OSI and TOS increased in ileum tissue in rats exposed to ischemia reperfusion, while TAS decreased (22). In a study of mesenteric artery occlusion and reperfusion induced in rabbits, Kılıç $\mathrm{K}$ et al. reported high MDA levels and low TAS (23). Türkmen $\mathrm{S}$ et al. reported similar findings from their experimental study of mesenteric ischemia. They observed a statistically significant increase in TOS and OSI values in the 30 min and $2 \mathrm{~h}$ ischemia groups compared to the control group. Although TAS levels decreased compared to the control group at both time periods, the difference was not statistically significant (24). No statistically significant difference in TAS, TOS, OSI or MDA levels between the ischemia group and control group in our study. Although TAS values decreased at each time interval (30 min, $2 \mathrm{~h}$ and $6 \mathrm{~h}$ ) compared to the control group, this decrease was not statistically significant. Oxidation and peroxidation of lipids, proteins, carbohydrates, and nucleic acids can create oxidative stress markers. Oxidation and peroxidation of amino acids give rise to a carbonyl group that can be detected in tissue or blood samples. An increasing number of studies have used measurements of plasma protein carbonyl in various different diseases (25).

In one study evaluating plasma protein carbonyl levels in serum of patients with chronic arterial occlusion, the average oxidase activity of plasma protein carbonyl was significantly higher than in the controls. Plasma protein carbonyl levels in blood specimens collected 14 days after surgery from patients with chronic ischemia decreased significantly compared to preoperative values (13). Tsukimori K et al. reported that serum protein carbonyl levels increased in association with oxidative stress in patients with preeclampsia compared to normal pregnant subjects (26).

Although significant histopathological differences occurred at all time periods between the mesenteric ischemia and control groups in our experimental study, we determined no statistically significant difference between the two groups in terms of plasma protein carbonyl levels. Oxidative stress markers have been determined to rise in many previous clinical and experimental studies of oxidative stress. However, no ischemia-related increase in oxidative stress markers was observed in this study. We are unable to account for the mechanism behind the absence of this 
anticipated variation. Similar and/or wider experimental and clinical studies and more detailed investigation of the relation between these markers and oxidative stress are now needed.

\section{Limitation}

Since this is an experimental study, it may differ from other clinical study and experimental study findings. Various environmental factors that could not be brought fully under control, such as physical parameters and laboratory conditions, may have affected the study findings. One of the main limitations of this study is that other biochemical parameters that have been shown to be capable of rising under ischemic conditions, such as IMA, were not used.

\section{Conflict of interest}

There is no conflict of interest.

\section{REFERENCES}

1. Oldenburg WA, Lau LL, Rodenberg TJ, Edmonds HJ, Burger CD. Acute mesenteric ischemia: a clinical review. Archives of internal medicine. 2004; 164(10): 1054-62.

2. Chang RW, Chang JB, Longo WE. Update in management of mesenteric ischemia. World journal of gastroenterology. 2006; 12(20): 3243.

3. Rosero O, Harsányi L, Szijártó A. Acute mesenteric ischemia: do biomarkers contribute to diagnosis? Orv Hetil. 2014; 155(41): 1615-23.

4. Akalın FA, Baltacıoglu E, Alver A, Karabulut E. Lipid peroxidation levels and total oxidant status in serum, saliva and gingival crevicular fluid in patients with chronic periodontitis. Journal of clinical periodontology.2007; 34(7): 558-65.

5. Rabus M, Demirbag R, Sezen Y, et al. Plasma and tissue oxidative stress index in patients with rheumatic and degenerative heart valve disease. Turk Kardiyol Dern Ars. 2008; 36(8): 53640 .

6. Aslan M, Cosar N, Celik H, et al. Evaluation of oxidative status in patients with hyperthyroidism. Endocrine. 2011; 40(2): 285-9.

7. Dalle-Donne I, Rossi R, Giustarini D, Milzani A, Colombo R. Protein carbonyl groups as biomarkers of oxidative stress. Clinica chimica acta. 2003; 329(1): 23-38.

8. Berlett BS, Stadtman ER. Protein oxidation in aging, disease, and oxidative stress. Journal of Biological Chemistry. 1997; 272(33): 20313-6.

9. Smith CD, Carney JM, Starke-Reed P, et al. Excess brain protein oxidation and enzyme dysfunction in normal aging and in Alzheimer disease. Proceedings of the National Academy of Sciences. 1991; 88(23): 10540-3.

10. Domínguez C, Ruiz E, Gussinye M, Carrascosa A. Oxidative stress at onset and in early stages of type 1 diabetes in children and adolescents. Diabetes Care. 1998(10): 1736-42.

11. Lih-Brody L, Powell SR, Collier KP, et al. Increased oxidative stress and decreased antioxidant defenses in mucosa of inflammatory bowel disease. Digestive diseases and sciences. 1996; 41(10): 2078-86.

12. Mantle D, Falkous G, Walker D. Quantification of protease activities in synovial fluid from rheumatoid and osteoarthritis cases: comparison with antioxidant and free radical damage markers. Clinica chimica acta. 1999; 284(1): 45-58.

13. Rutkowska M, Strzyewski K, Iskra M, PioruńskaStolzmann M, Majewski W. Increased protein carbonyl groups in the serum of men with chronic arterial occlusion and the effect of postoperative treatment. Med Sci Monit. 2005; 11(2): CR79-83. 
14. Yagi K. Lipid peroxides and related radicals in clinical medicine. Adv Exp Med Biol. 1994; 366: 115.

15. Erel O. A novel automated direct measurement method for total antioxidant capacity using a new generation, more stable ABTS radical cation. Clin Biochem. 2004; 37(4): 277-85.

16. Gunduz A, Turkmen S, Turedi S, et al. Timedependent variations in ischemia-modified albumin levels in mesenteric ischemia. Acad Emerg Med. 2009; 16(6): 539-43.

17. Abboud B, Daher R, Boujaoude J. Acute mesenteric ischemia after cardio-pulmonary bypass surgery. World J Gastroenterol. 2008; 14(35): 5361-70

18. Marshall JC, Vincent JL, Fink MP, et al. Measures, markers, and mediators: toward a staging system for clinical sepsis. A report of the Fifth Toronto Sepsis Roundtable, Toronto, Ontario, Canada, October 25-26, 2000. Crit Care Med. 2003; 31(5): 1560-7.

19. Gonullu D, Yankol Y, Işiman F, Akyildiz Igdem A, Yucel O, Koksoy FN. pH value and potassium level of diagnostic peritoneal lavage fluid in the early diagnosis of acute mesenteric ischemia secondary to arterial occlusion in rats. Ulus Travma Acil Cerrahi Derg. 2007; 13(4): 261-7.

20. Slater TF. Free-radical mechanisms in tissue injury. Biochem J. 1984; 222: 1-15.

21. Paterno F, Longo WE. The etiology and pathogenesis of vascular disorders of the intestine. Radiol Clin North Am. 2008; 46(5): 877-85.

22. Terzi A, Coban S, Yildiz F, et al. Protective effects of Nigella sativa on intestinal ischemia-reperfusion injury in rats. J Invest Surg. 2010; 23(1): 21-7.
23. Kiliç K, Hanci V, Selek S, et al. The effects of dexmedetomidine on mesenteric arterial occlusionassociated gut ischemia and reperfusion-induced gut and kidney injury in rabbits. J Surg Res. 2012; 178(1): 223-32.

24. Turkmen S, Sahin A, Gunaydin M, et al. The value of signal peptide-CUB-EGF domain-containing protein-1 (SCUBE1) in the diagnosis of pulmonary embolism: a preliminary study. Acad Emerg Med. 2015; 22(8): 922-6.

25. Rolim MF, Riger CJ, Eleutherio EC, Colão Cda F, Pereira GC, Schanaider A. Colonic healing after portal ischemia and reperfusion: an experimental study with oxidative stress biomarkers. Redox Rep. 2007; 12(6): 267-74.

26. Tsukimori K, Yoshitomi T, Morokuma S, Fukushima K, Wake N. Serum uric acid levels correlate with plasma hydrogen peroxide and protein carbonyl levels in preeclampsia. Am J Hypertens. 2008; 21(12): 1343-6. 